\title{
Manufacturing of Femoral Heads from Ti-6Al-4V Alloy with High Speed Machining: 3D Fi- nite Element Modelling and Experimental Validation
}

N.I. Galanis, A.P. Markopoulos*, I.D. Giannakopoulos, D.E. Manolakos

*Laboratory of Manufacturing Technology, National Technical University of Athens, 9, Iroon Polytechniou Avenue, 15780 Athens, Greece. amark@ mail.ntua.gr

Titanium alloys are used for the manufacturing of femoral heads for orthopaedic implants. Poor machinability of these materials, especially at high speeds, creates the need for more detailed investigations on this subject. The at hand study analyzes the construction of 3D Finite Element Method (FEM) models pertaining to the manufacturing of femoral heads made from Ti-6Al-4V. For this purpose a commercial FEM programme is employed, specialising in machining modelling, namely AdvantEdge. The validation of the model is provided through experiments on actual femoral heads cut in a CNC lathe at high cutting speeds. Comparison between experimental and numerical results on cutting forces and chip morphology exhibits a good agreement, indicating the success of the proposed models. These 3D models can be used for realistically estimating the influence of cutting conditions on the final product, without performing time and money consuming experiments.

Keywords: Femoral Heads, High Speed Machining, Titanium alloys, FEM Modelling, Chip Morphology

\section{References}

[1] ARRAZOLA, P.J., ÖZEL, T. (2010). Investigations on the effects of friction modeling in finite element simulation of machining. International Journal of Mechanical Sciences. 52, pp. 31-42.

[2] BAEKER, M., ROESLER, J., SIEMERS, C. (2002). A finite element model of high speed metal cutting with adiabatic shearing. Computers and Structures, 80, pp. 495-513.

[3] BAEKER M. (2006). Finite element simulation of high-speed cutting forces. Journal of Materials Processing Technology. 176, pp. 117-126.

[4] BIL, H., S., KILIC, S.E., TEKKAYA, A.E. (2004). A comparison of orthogonal cutting data from experiments with three different finite element models. International Journal of Machine Tools and Manufacture. 44, pp. 933944.

[5] BLACK, J.T.. HUANG, J.M. (1996). An evaluation of chip separation criteria for the FEM simulation of machining. Journal of Manufacturing Science and Engineering. 118, pp. 545-553.

[6] CHILDS, T.H.C., MAEKAWA, K. (1990). Computer-aided simulation and experimental studies of chip flow and tool wear in the turning of low alloy steels by cemented carbide tools. Wear. 139, pp. 235-250.

[7] CHILDS, T.H.C., RAHMAD, R. (2009). The effect of a yield drop on chip formation of soft carbon steels. $M a-$ chining Science and Technology. 13, pp. 471-487.

[8] DIRIKOLU, M.H., CHILDS, T.H.C. AND MAEKAWA, K. (2001). Finite element simulation of chip flow in metal machining. International Journal of Mechanical Sciences. 43, pp. 2699-2713.

[9] EZUGWU, E.O., WANG, Z.M. (1997). Titanium alloys and their machinability - a review. Journal of Materials Processing Technology. 68, pp. 262-274.

[10] FANG, G., ZENG, P. (2005). Three-dimensional thermo-elastic-plastic coupled FEM simulations for metal oblique cutting processes. Journal of Materials Processing Technology. 168, pp. 42-48.

[11] FANG, N., WU, Q. (2009). A comparative study of the cutting forces in high speed machining of Ti-6Al-4V and Inconel 718 with a round cutting edge tool. Journal of Materials Processing Technology. 209, pp. 4385-4389.

[12] FILICE, L., MICARI, F., RIZZUTI, S., UMBRELLO, D. (2007). A critical analysis on the friction modelling in orthogonal machining. International Journal of Machine Tools and Manufacture. 47, pp. 709-714.

[13] GALANIS, N.I., MANOLAKOS, D.E. (2009). Surface roughness of manufactured femoral heads with high speed turning. International Journal of Machining and Machinability of Materials. Vol.5, No.4, pp.371 - 382.

[14] GRZESIK, W., NIESLONY, P. (2012). Coupled thermo-mechanical FEM-based modelling of the tool-chip contact behaviour for coated cutting tools. International Journal of Machining and Machinability of Materials. Vol.11, No.1, pp. $20-35$.

[15] KOMVOPOULOS, K., ERPENBECK, S.A. (1991). Finite element modeling of orthogonal metal cutting. ASME Journal of Engineering for Industry. 113, pp. 253-267.

[16] KOSE, E., KURT, A., SEKER, U. (2008). The effects of the feed rate on the cutting tool stresses in machining of Inconel 718. Journal of Materials Processing Technology. 196, pp. 165-173. 
[17] KUNDRÁK, J. (2011). Alternative machining procedures of hardened steels. Manufacturing Technology. 11, pp. 32-39.

[18] KUNDRÁK, J., KARPUSCHEWSKI, B., GYANI, K., BANA, V. (2008). Accuracy of hard turning. Journal of Materials Processing Technology. Vol. 202, Is. 1-3, pp. 328-338.

[19] LIN, Z.C., LIN, S.Y. (1992). A couple finite element model of thermo-elastic-plastic large deformation for orthogonal cutting. ASME Journal of Engineering for Industry. 114, pp. 218-226.

[20] MARKOPOULOS, A.P. (2012). Finite Element Method in Machining Processes. Springer, London, UK

[21] MURR, L.E., QUINONES, S.A., GAYTAN, S.M., LOPEZ, M.I., RODELA, A., MARTINEZ, E.Y., HERNANDEZ, D.H., MARTINEZ, E., MEDINA, F., WICKER R.B. (2009). Microstructure and mechanical behavior of Ti-6Al-4V produced by rapid-layer manufacturing, for biomedical applications. Journal of the mechanical behavior of biomedical materials. 2, pp. $20-32$.

[22] NARUTAKI, N., MURAKOSHI, A., MOTONISHI, S., TAKEYAMA, H. (1983). Study on Machining of Titanium Alloys. Annals of the ClRP. Vol. 32/1, pp. 65-69.

[23] NOVAK, M. (2011). Surface quality of hardened steels after grinding. Manufacturing Technology. 11, pp. 55-59.

[24] SCHULZ, H., MORIWAKI, T. (1992). High-Speed Machining. Annals of the CIRP. Vol. 41/2, pp. $637-643$.

[25] SHIH, A.J. (1995). Finite element simulation of orthogonal metal cutting. ASME Journal of Engineering for Industry. 117, pp. 84-93.

[26] SHIH, A. J. (1996). Finite element analysis of the rake angle effects in orthogonal metal cutting. International Journal of Mechanical Sciences. Vol. 38/1, pp. 1-17.

[27] STRENKOWSKI, J.S., CARROLL, J.T. (1986). Finite element models of orthogonal cutting with application to single point diamond turning. International Journal of Mechanical Sciences. 30, pp. 899-920.

[28] STRENKOWSKI, J.S., MOON, K.J. (1990). Finite element prediction of chip geometry and tool/workpiece temperature distributions in orthogonal metal cutting. ASME Journal of Engineering for Industry. 112, pp. 313-318.

[29] SUKAYLO, V.A., KRUKOVSKY, P.G., KALDOS, A., LIERATH, F., KUNDRAK, J., EMMER, T. (2003). Computer-based modelling of thermal distortions in turning. Proceedings of the Institution of Mechanical Engineers Part B-Journal of Engineering Manufacture. Vol. 217, No. 3, pp. 363-371.

[30] SUN, S., BRANDT, M., DARGUSCH, M.S. (2009). Characteristics of cutting forces and chip formation in machining of titanium alloys. International Journal of Machine Tools and Manufacture. 49, pp. 561-568.

[31] UHLMANN, E., GRAF, M., ZETTIER, R. (2007). Finite Element Modeling and Cutting Simulation of Inconel 718. Annals of the CIRP. Vol. 56/1, pp. 61-64.

[32] USUI, E., SHIRAKASHI, T. (1982). Mechanics of machining - from "descriptive" to "predictive" theory. In: Kops, L. and Ramalingam S., (Eds.) On the art of cutting metals - 75 Years Later: a tribute to F.W. Taylor, Proc. of the winter annual meeting of the ASME PED. 7, pp. 13-35

[33] YEN, Y.-C., SÖHNER, J., LILLY, B., ALTAN T. (2004). Estimation of tool wear in orthogonal cutting using the finite element analysis. Journal of Materials Processing Technology. 146, pp. 82-91.

[34] ZHANG, B., BAGCHI, A. (1994). Finite element formation of chip formation and comparison with machining experiment. ASME Journal of Engineering for Industry. 116, pp. 289-297. 